\title{
Impact of Enhanced Enterprise Resource Planning (ERP) on Firm Performance through Green Supply Chain Management
}

\author{
Zeplin Jiwa Husada Tarigan ${ }^{1, *(1)}$, Hotlan Siagian ${ }^{1}\left(\mathbb{D}\right.$ and Ferry Jie ${ }^{2}(\mathbb{D}$ \\ 1 Department of Master Management, Faculty Business and Economics, Petra Christian University, \\ Siwalankerto 121-131, Surabaya 60236, Indonesia; hotlan.siagian@petra.ac.id \\ 2 School of Business and Law, Edith Cowan University, Joondalup 6027, Australia; f.jie@ecu.edu.au \\ * Correspondence: zeplin@petra.ac.id; Tel.: +62-312983244 or +62-312983145
}

Citation: Tarigan, Z.J.H.; Siagian, H.; Jie, F. Impact of Enhanced Enterprise Resource Planning (ERP) on Firm Performance through Green Supply Chain Management. Sustainability 2021, 13, 4358. https://doi.org/ $10.3390 /$ su13084358

Academic Editors: Andrea Appolloni and Wen-Hsien Tsai

Received: 5 March 2021

Accepted: 10 April 2021

Published: 14 April 2021

Publisher's Note: MDPI stays neutral with regard to jurisdictional claims in published maps and institutional affiliations.

Copyright: (c) 2021 by the authors. Licensee MDPI, Basel, Switzerland. This article is an open access article distributed under the terms and conditions of the Creative Commons Attribution (CC BY) license (https:/ / creativecommons.org/licenses/by/ $4.0 /)$.

\begin{abstract}
This study investigates the impact of enhanced enterprise resource planning (ERP) on firm performance through green supply chain management, supplier integration, and internal integration. The population is the manufacturer domiciled in East Java, Indonesia, which has implemented ERP and been certified by the International Organization for Standardization (ISO) in the environmental management system. Data collection used a questionnaire designed with the five-point Likert scale. Of 243 manufacturers, 150 questionnaires were distributed, and 135 questionnaires are considered valid for analysis. Data analysis used smart PLS software. The result indicated that all eight predetermined hypotheses were supported. Enhanced ERP affects supplier integration, internal integration, and green supply chain management. Internal integration affects green supply chain management and firm performance. Supplier integration affects green supply chain management and firm performance. Green supply chain management affects firm performance. An interesting finding is that green supply chain management, internal integration, and supplier integration mediate the effect of enhanced ERP on firm performance. This study's novelty lies in the research model that analyzes the relationship between the four constructs simultaneously with the green supply chain management, internal integration, and supplier integration as a mediating variable. The research provides an insight for the manager on how to improve the firm performance in supply chain management. This study could also contribute to the current research in supply chain management.
\end{abstract}

Keywords: enhanced ERP; GSCM; supplier integration; internal integration; firm performance

\section{Introduction}

The rapid development of information technology entails that companies make adjustments to keep the enterprise resources planning (ERP) system upgraded to the latest technology advancement in manufacturing processes. Every company makes every effort to improve productivity, efficiency, speed, and service, innovating to stay ahead and survive in the market. In addition to productivity and efficiency, companies must also understand and know what is needed by consumers. Supply Chain Management is an approach to achieving a more efficient integration of related organizations within a supply chain: suppliers, manufacturers, distributors, retailers, and customers. Supply chain management adoption enables the company to integrate the material and service procurement activities, conversion into semi-finished goods and final products, and delivery to customers [1].

Supply chain management is an approach applied to bring together suppliers, entrepreneurs, warehouses, and other storage areas (distributors, retailers, and retailers), so that products can be produced and distributed in the right amount, the right location, and the right time meanwhile reducing the costs and meet customer needs [2]. Supply chain management is essential for the company the pursuit of product sustainability in the marketplace. The company implements green supply chain management (GSCM) to increase the company's competitiveness by taking into account the issue of the company's environmental conditions [3]. The company, adopting the green supply chain management, 
needs to communicate with the company's upstream, downstream companies. The GSCM takes care of reducing waste, use raw materials efficiently, and result in a minimum impact on the environment. For this goal, the company usually adopts a new or innovative process. The implementation of GSCM represents a positive image to the community in reducing pollution to the environment and can meet and even exceed local government regulations' limits when the company implements it [4]. GSCM will be easily implemented when the company can implement information technology that is integrated internally and externally. Information technology in use by companies such as ERP systems can fully integrate all related partners within a supply chain. This ERP system also ensures that one department with other departments is integrated and uses a single database system [5].

The ERP system enables the enterprise to build internal integration between departments and external integration with suppliers and customers [6]. This integration allows the company to reduce production costs by collaborating with suppliers and customers [7]. The adoption of the ERP system by the company provides the company an overview of internal conditions by providing regular reports on the availability of raw materials, which, in the end, enables the supplier to provide the company's needs. The supplier can also provide the schedule progress every day, making it easier for marketing, production, and transportation departments to provide delivery on time, provide data about the raw materials and goods received in the warehouse to facilitate the purchasing, warehouse, and planning department in forecasting raw material requirement [8].

Internal integration in the company enables the company to quickly share information between cross-functional departments to improve response changes [9]. The company's internal integration provides excellent communication and collaboration between synchronizing processes, synchronizing in meeting customer needs, and synchronizing with suppliers in procuring material [1]. Internal integration can better understand the work and impact in carrying out company policies to adopt GSCM. The company's information technology will provide advantages for the company, including fast and precise data transfer and access, reduced use of paper for the company, faster communication, coordination between departments, and data in real-time.

Supplier integration is considered the primary managerial strategy to improve purchasing performance, and customer integration to improve operational performance [10]. The integration of suppliers aimed at creating a rapid supply network structure. The company's ability to build integration with suppliers can provide efficiency in the procurement of raw materials, on-time delivery of raw materials, company flexibility, and increase company performance. The integration built by the company with suppliers can collaborate so that the flow of products, services, financial information, and decision making together provides effectiveness and efficiency for the company [11].

Integration with suppliers gives suppliers trust in managing information to share information with suppliers to provide its needs. ERP systems can provide integration within the company so that it has an impact on green supply chain management practice [1] Green Supply chain Management practices conducted by the company include selecting and evaluating suppliers, submitting to suppliers in managing company inventory, ecodesign, packaging, reverse logistics at the company, and building active cooperation with suppliers. Indonesia currently provides secondary pollution globally, so the government is currently assessing companies to produce environmentally friendly products. This condition resulted in manufacturing companies trying hard to implement green supply chain management using an ERP system that has long been implemented. Companies increase internal and external integration of the company to be able to use environmentally friendly raw materials and environmentally friendly processes in order to be able to maintain the company's operational performance $[7,10]$. The companies in Indonesia are trying to quickly adjust its operational conditions to the government's regulations.

Corporate care is very important for the environment by considering implementing green in its supply chain flow. Green supply chain control for manufacturing companies is an important thing to maintain its sustainability by considering implementing regula- 
tions that apply to a country. The Government of Indonesia, through regulations of the Government of the Republic of Indonesia, has strictly regulated environmental protection and management. The environment is a unity of space with all objects, power, conditions, and living things, including humans and their behavior, which affect nature itself, the continuity of life, and humans' welfare and other living things. Sustainable development determined by the Government of Indonesia is a conscious and planned effort to integrate environmental, social, and economic aspects into a development strategy to ensure environmental integrity and the safety, capability, welfare, and quality of life of present and future generations.

In summary, the above discussion has revealed five constructs that authors consider to examine in this study, namely, enhanced ERP, GSCM, supplier integration, internal integration, and firm performance. The previous research has examined the direct relationship between two consecutive constructs, and the previous research has been conducted during the normal situation. This study will fill in the gap to examine the relationship between the five constructs in a single model dealing with enhanced ERP impact on firm performance through supplier integration, GSCM, and internal integration. This study's novelty lies in the proposed research model, which does not exist before, and the study is conducted during the covid-19 Pandemic. This research model consequently raised three mainstream research questions to be examined as follows: 1) does enhance ERP improve supplier integration, GSCM, and internal integration, 2) does supplier integration, GSCM, and internal integration directly influence firm performance, 3) does enhanced ERP directly improve firm performance through mediating role of supplier integration, GSCM, and internal integration. This paper's main goal is to examine the research questions and whether the built model works well amid the Covid-19 pandemic era. This study is highly important because it could provide insight for practitioners and managers on improving the firm's performance in supply chain management. This paper also could contribute to the current research in the supply chain management theory.

\section{Literature Review}

\subsection{Green Supply Chain Management}

Green supply chain management (GSCM) is a concept of the supply chain in the procurement of materials, the company's production processes, and distribution of company products by taking into account the company's environment in order to be able to maintain sustainability of the company [1,12]. GSCM is essential for companies because the community pressures it as customers and government institutions through the regulations set [4]. Companies must practice GSCM in producing products following customer demand and regulations set by the government [3].

GSCM is now essential for companies to increase the level of efficiency and effectiveness in producing products. Research conducted by Famiyeh et al. [3] in measuring green supply chain management using that there is cooperation with suppliers in paying attention to the environment, conducting audits of suppliers related to the environment, providing environmentally friendly product information for end-users, requiring suppliers to have certification related to the environment and monitoring and considering the level pollution and waste for suppliers. Sharma and Gandhi's research [13] measures green supply chain practices regarding environmental certification, preventing pollution, designing environmentally friendly products, life cycle assessment, and reverse logistics. Wang and Dai [14] state that GSCM practices, consisting of internal and external management, impact environmental performance, social performance, and improve financial firm performance. Companies always try to improve the environment and social community in order to maintain the environmental sustainability. This approach provided a guide for the company, such as in the material procurement and improving customer satisfaction, which is the goal of GSCM [15].

Research Laosirihongthong et al. [4] measured green supply chain practices as green purchasing practices, eco-design practices, reverse logistics practices, legislation, and 
regulatory practices. Best practice in implementing green procurement is determined by motivation and barriers from external and internal companies to improve the environment, financial and operational performance [16]. GSCM is practically based on the green SCOR consisting of the plan, source, make, deliver, and return [17]. Adopting GSCM practices enable furniture manufacturing companies to maintain a sustainable supply chain.

Al-Ghwayeen and Abdallah's research [12] measured green supply chain management using eco-design, green purchasing in raw material procurement, internal environmental management, and cooperation with customers. Research conducted by Luthra et al. [18] measured green supply chain practice, Green product development, Green design, Green purchasing, and green raw material procurement, Green manufacturing, and Green transportation and distribution. This study establishes indicators in measuring GSCM is cooperation with suppliers (GSCM1) [3], green purchasing (GSCM2) [18], green manufacturing (GSCM3) [18], policy management (GSCM4) [4], and government regulations (GSCM5) [4].

\subsection{Supplier Integration}

The company builds supply chain integration through integration with its material suppliers and integration with the corporate purchasing department. Consumer integration focuses on the relationship between seller and buyer. The company or organization will implement several new components to meet its customers' needs, such as product innovation or innovation in serving customers. This action can increase the company's competitiveness with its competitors [19]. Consumer integration is the active involvement of companies in improving product quality and increasing operational effectiveness to maintain good relations and increase customer satisfaction. Consumers can also provide feedback to companies on whether the company has fulfilled their desires and overall satisfaction [20]. Supplier integration is a collaboration between a buyer's company and its related suppliers in the process of entering supplies to buyer's companies for mutually acceptable results. Supplier integration is an activity that involves suppliers and retailers. Activities undertaken include selecting products to sell, decisions about how to determine prices and market products, and ensuring that products are delivered to the store on time, integration can be suitable or unsuitable [21]. Supplier integration is an integration built to collaborate between suppliers and companies in formulating material procurement strategies, implementation, and behavior of the two organizations to improve company performance in construction companies in Korea [22]. This integration includes collaborative decision-making processes to achieve an efficient flow of resources among members of the supply chain and adjusting strategies that refer to consistency in developing and implementing policies in improving organizational performance between the company and its partners [11].

The measurement indicators consist of, firstly, the companies share information with their suppliers (related to sales forecasts, production plans, delivery status, and stock levels); and secondly, collaborative development with significant suppliers (related to supplier development, product design, sharing risks or values, and long-term agreements), joint decision making, and system coupling with major suppliers [11]. Measuring the external integration used in the study of Woo et al. [22], among others, can achieve goals together, able to build mutual understanding and responsibility of risk, build partnerships with suppliers to pay attention to the environment, share planning with our partners, and share resources, skills, and knowledge to strengthen collaboration. Supplier integration measurements the extent to which the company shares the master production schedules with critical suppliers, determining shared goals with key suppliers, identifying and determining new markets together with key users, always sharing new ideas with key suppliers, and sharing best practices with key suppliers [23]. The indicators used are sharing information with suppliers (S.In1) [11], collaborating with suppliers (S.In2) [11], determining shared goals with suppliers (S.In3) [23], sharing ideas in innovating processes (S.In4) [19], and determining decisions together with suppliers (S.In5) [11]. 


\subsection{Internal Integration}

Internal integration is a process that occurs within a company involving interaction between departments. Internal integration is a process carried out to facilitate interaction, communication, and collaboration between the company's functions in achieving the company goals [24,25]. Effects arising from departments' interactions can be positive if the interactions that arise are overall good [26]. Internal integration is vital for customers. The level and quality of internal integration affect the position of a company in the eyes of customers. The higher the internal integration of a company, the better the company's performance [27].

Internal integration is one way for companies to provide some information that includes functions and activities that integrate. In achieving internal integration in an organization, managers usually use enterprise resources planning (ERP) systems [28]. Internal integration is built by the company so that synchronization and collaboration between departments within the company can be adjusted to suppliers and customers [29]. The area of function in companies related to different departments is integrated to fulfill customer orders. Cross-functional of the company to do joint planning, share information between departments, and work together to achieve the goals set [30].

The company integrates between departments related to manufacturing, distribution, customers, and suppliers determined by integrating functions within the company to increase competitiveness in the long run [2]. Internal integration measurement conducted is measured by information systems management and process control [31]. Management of information systems is measured by sharing about defects in the company's production floor, sharing production schedules with the relevant departments, and sharing information about machine breakdowns with the relevant departments. Processes measure process control on the production floor, and process capabilities and equipment on the production floor are jointly controlled.

The measurement indicator of internal integration is sharing information with the purchasing department (sharing sales forecast, sharing production plans, sharing production progress in the company and stock level inventory), together with the purchasing department in making decisions, sharing information with the purchasing department and sharing- the same as the sales department in making decisions [11]. Demeter et al. [32] used the measurement indicator for internal integration as sharing information with other departments, jointly making decisions, sharing innovation between departments, making innovations for companies, using information technology to support communication between departments, and building a performance management system with other departments. Research conducted by Jajja et al. [11] and Titah et al. [33] become an indicator of this research related to internal integration, namely, joint decisions between departments concerned with considering company margins (In. I1) [11], joint decisions between departments related to inventory levels (In.I2) [11], sharing decisions related to company goals (I.In3) [11], sharing decisions related to pricing (I.In4) [33], and sharing related decisions with product shipments (I.In5) [33].

\subsection{Enhanced ERP}

Companies are trying to build information technology systems to adapt to changes in the company's external environment. Adaptation is an ability that must be done in a company to face a significant change and influence the company's management system. ERP system is a technology system used in building company competitiveness because it can provide operational excellence [34]. It is indispensable for a company to survive and sustainable the intense competition and fasts. ERP system is an information technologybased system that can integrate its business functions to be integrated and efficient [35]. The company is also able to adjust quickly by knowing the real condition of the company. The company's real condition provides information inside and outside the company using integrated information technology called enterprise resources planning (ERP). An inte- 
grated system enables the organization to share the information with all functions and enhances ERP users' satisfaction and benefit from using the ERP system [36].

ERP system can also be said as a software system that can integrate all business functions of a company; as a place for sharing information, knowledge data within the organization as a container for company automation systems and access to information that can provide data in real-time [8]. The companies always try to adjust the ERP according to its needs, the company's operational system's uniqueness, and the company's key user and end-user [37]. Changes in the ERP configuration system will present huge costs and risks when implemented [34]. The indicator used by Elkhani et al. [38], the ERP system usage, uses the ERP system intensively, often using the ERP system at work, and overall, always using ERP. The measurement used in this study adopted Tarigan et al. [39] and Ince et al. [40], namely ERP system quality function (EERP1) [39], ERP system information quality (EERP2) [39,40], ERP system used intensively (EERP3) [40], ERP system on personal impact (EERP4) [39,40], and ERP system on organizational impact (EERP5) [40].

\subsection{Firm Performance}

Firm performance results obtained from a company's management activity and used by the company to be a benchmark parameter in assessing company management's success [41]. Performance measurement of the company continues to grow, which includes measurements and uses qualitative and quantitative approaches. The company's management always pays attention to the company's operational achievements and finances [16]. Company performance is produced from the process of activities within the company during specific periods concerning predetermined standards. Companies control operational performance in general by using periods of the daily, weekly, monthly, quarterly, semester, and yearly achievement periods. This activity is controlled continuously to understand the progress of the company's operating results.

The company determines the measurement of financial performance to consider the return on investment, profitability, market share, revenue growth at a more competitive rate and is carried out in monthly, quarterly, semester, and annual periods. Performance measurement systems have tangible and intangible measures with a balance of the two types used to measure performance. Building an ethical supply chain system can undoubtedly be a significant determinant in improving company performance. This relationship can develop an innovation that can help companies improve productivity and quality of production processes in the supply chain to produce products, control costs, and supplier relationships that affect overall company performance [42]. According to Ince et al. [40], the measurement of company performance is divided into two, namely, financial performance and market performance. Criteria for measuring financial performance are increasing sales profit margins and increasing ROI (Return on Investment) value. In comparison, the criteria for measuring market performance are sales growth, market share growth, and other competitiveness improvements.

Al-Shboul et al. [2] state that market performance and financial performance measure firm performance. Market performance is measured using the company's ability to have market share, its ability to have market share growth, and its ability to have sales growth. Measurements used by using financial performance are measured by ROI, the company's ability to have ROI growth, the company's profit margin, and the company's competitiveness at this time. Chong et al. [41] used indicators to measure organizational performance, including reducing lead time, increasing inventory turnover speed, reducing defective products, reducing product returns from customers, sales levels, cost reduction, and meeting customer requirements. Firm performance measured in the study of Gandhi et al. [13] return on assets, revenues, and profits of the company. Measurement of operational performance reduces management costs, reduces lead-time, reduces in order time, reduces material damage, and reduces late delivery level [43]. Performance measurements used to concern the operational side are determined delivery accuracy, increased flexibility, ability to fulfill orders, and increased customer satisfaction [5]. This study determines com- 
panies' performance with non-financial performance data on manufacturing companies. The financial performance is difficult in getting data from manufacturing companies due to the high level of confidentiality that companies have. The indicators used in this study are the quality of the products produced by the company (FP1) [41,43], reduction of production costs (FP2) [5,41], reducing lead time (FP3) [41,43], reducing the company's inventory level (FP4) $[5,41]$, and reducing product returns from customers (FP5) [41].

\section{Relations between Concepts}

\subsection{Relationship between ERP System Enhance Concept and Supplier Integration}

Alignment of the role of ERP systems in the company can build integration with the company's suppliers. The role of ERP contributes to building a single database system that companies can use to share with suppliers. Integration suppliers are built by companies to build collaboration in providing information using information technology [22]. The organization currently has a lot of integrating existing data in the company and allows it to be integrated with the supplier partners to fulfill customer demands $[33,44]$. Integrated information technology can build integration with suppliers in integrating planning and coordinating production lines with major suppliers [45]. The usage of the integrated information systems is necessary to synchronize the company with the supply. The integration of information technology can enable the integration of suppliers with companies in terms of production planning and capacity, delivery of orders, and stock levels promptly that has more directly interacted with suppliers. An ERP system can be used by an organization to build an effective system to improve user satisfaction [34]. Integration can maintain the flow of material following the production process's rhythm and adjusted to the suppliers [46]. The company cooperates with suppliers in sharing information with key suppliers and collaborates with suppliers using information technology that is integrated with suppliers [32]. ERP allows the company to respond quickly and proactively to the company customer requirement to pursue a sustainable supply chain. ERP also enables the company to respond reactively to adjust to the environment. Whereas the company proactively carried out integration with suppliers and customers to achieve company goals [47].

Hypotheses 1 (H1). Enhanced ERP systems affect supplier integration.

\subsection{Relationship between the Enhance ERP System Concept and Internal Integration}

ERP adjustments to the company will provide a company system that is always updated and makes it a source of information used by all company components. The role of ERP is essential in building a company's internal integration using a single database. With internal integration within an organization, managers can use ERP technology to assimilate data from departments throughout the organization [48]. Information technology enables practitioners to search and understand incoming data in real-time and adjust operational settings as needed. Managers can then develop integrated processes to improve the flow of goods and information between various departments and functional areas within an organization [48]. The database used together with the company to provide fast and complete information will facilitate decision-making to minimize supply chain risk, which creates an imbalance between supply and demand. The speed of decision-making for internal integration and external integration is vital for companies to maintain stability in an unstable market [49]. Information sharing built and coordinated among cross-functional departments positively and significantly impacts the logistics services supply chain's integration capability in service providers companies in China [50]. The information technology owned by the ERP companies can increase the external integration, which is built between the companies and their supplier, by sharing real-time data so both parties can adjust their planning and scheduling based on the actual practices [51].

Within an integrated organization, employees utilize information technology to quickly detect inventory and demand levels in overcoming the consequences of various supply chain issues. Internal integration also allows information processing and allows organizations to respond to real risks in the supply chain [52]. Internal integration 
enables organizations to connect and coordinate better throughout the company when responding to various supply chain risks [26]. Decision-making quickly, managers must take the initiative to develop an integrative relationship with individuals in using available information technology [49]. The use of information technology can provide balanced information to all company departments to determine the risks faced. Internal integration within the company will enable all departments to access the company's products and monitor its operational processes to reduce its operational performance by increasing its operational performance [32]. Companies use ERP to respond to internal companies to ensure that business processes between the company's functions run well and achieve optimal resources [47].

Hypotheses 2 (H2). Enhanced ERP systems affect internal integration.

\subsection{Relationship between the Enhanced ERP System Concept and Green Supply Chain Management}

ERP system customization ensures that the company has used integrated information technology as a single system. The company's ability to adjust the ERP system impacts paper use, declining, and even eliminating paper usage in its departments. Eco-collaboration with external parties is very beneficial for companies when building plans using integrated information technology [12]. Material flow and integrated information flow in the supply chain will impact the fulfillment of processes or products to corporate customers using information technology to reduce the natural environment's impact [3]. Environmental management practices in building information technology companies can build integration with suppliers and customers to implement green supply chain management [53].

Hypotheses 3 (H3). Enhanced ERP systems affect green supply chain management in companies. 3.4. Relationship between the Concept of Internal Integration with Green Supply Chain Management

Internal integration within the company allows exchanging information from one department to another and between employees and employees. The use of information technology increases companies' intensity in sharing information and shows how well organizations communicate critically [39]. Developing competencies with internal integration, sharing information, and training can improve GSCM in organizations. Improvements in the supply chain occur because internal employees and external supply chain partners become better connected to coordinate various organizational policies related to its material inventory and decrease production costs [22]. Internal integration and information technology allow individuals throughout the supply chain to share information about the risks that occur, minimizing the impact of consequences on the supply chain. This internal integration and information technology allow managers to collect, coordinate, and disseminate data about supply chain risks and then use that information to manage the balance between supply and demand. Internal integration enables collaboration across internal boundaries [54] and facilitates interaction while also allowing communication to be carried out quickly. Internal integration by the company can initiate the interaction during the procurement of materials with the suppliers in the global sourcing environment [55].

Hypotheses 4 (H4). Internal integration affects the green supply chain management.

\subsection{Relationship between Supplier Integration and Green Supply Chain Management}

The integration built by the company with external parties can provide environmentally friendly materials and sub-materials. Integration with suppliers provides stability for the company in procuring materials and strengthening its partnership with suppliers. The integration process in supply chain management is reflected in suppliers and buyers [56]. The findings show that there is cognitive consistency about intra-company factors that influence inter-company internal integration activities, which constitute an internal collaborative culture and internal synchronous practices that will influence supplier integration because of the sharing of collaboration attributes synchronization. In this finding, it can be seen that there are results of an investigation into intra-company factors and activities so that it can be a starting point for understanding managerial attitudes towards something 
more complex in inter-integration activities within the company [45]. The findings revealed that the integration of customer and supplier integration could positively affect internal integration. So, companies that implement customer and supplier involvement need to increase internal integration in the company. This integration can influence customer involvement in internal integration that is greater than the involvement of integration suppliers alone. This study looks more closely at manufacturing flexibility and internal integration literature to understand the triadic relationship between internal integration, internal flexibility, and external flexibility [57]. Integration with supplier and customer in sharing knowledge improved the company's operational performance [32].

Hypotheses 5 (H5). Supplier integration affects green supply chain management.

\subsection{Relationship of Supplier Integration with Firm Performance}

Internal integration positively influences the organization's ability to improve, both directly and indirectly [28]. Companies must increase supply chain flexibility and develop competencies through internal integration, information sharing, and training to overcome various supply chain risks. With internal integration, companies can coordinate resources to restore the supply chain in stable conditions. Internal integration allows the supply chain of resources to detect various obstacles [26]. A manager can carry out internal integration to identify gaps in the supply chain and communicate information about the affected parties' possible consequences. This information technology helps to review the availability of the company's inventory to know the appropriate supply strategy to avoid the risk of an imbalance in the number of requests with the amount of raw material supply that might occur. When there is an unexpected surge in demand, management utilizes information technology to identify alternative supply sources and replenish needed supplies. Supplier integration enables the company to integrate with suppliers and synchronize planning, production processes, and customer demand. The same concept can be applied to practice as supplier innovation, supplier development, and supplier quality improvement [45]. The trust among shareholders, which is built upon the willingness to cooperate between the companies and their suppliers, will create stronger intensity to collaborate in finding optimal solutions to reduce overall costs and increase profitability [51].

Integration with external parties, especially suppliers, needs to inform the company about the quantity and quality of the material supplied and the constraints faced to inform its customers. This condition will provide good relations for the company and product prices company [33]. Internal integration and knowledge transfer can provide an increase in company performance [58]. The success of supplier integration will provide fast information for companies to increase company performance effectiveness and efficiency [23]. Integration with suppliers enables companies to complement and strengthen human resources so that collaborative partnerships between companies and suppliers occur and enable companies to maximize company performance [32]. The company's ability to build integration with its suppliers can build collaboration to reduce its performance [59]. The information sharing with external partners is carried out in a timely, complete, reliable, and adequate manner, enabling improved retail performance in Australia [60].

Hypotheses 6 (H6). Supplier integration affects firm performance.

\subsection{Relationship between the Concept of Internal Integration with Firm Performance}

The exchange of information in internal integration will create opportunities where optimization can be done by reducing the bullwhip effect and contributing to improved performance [44]. A well-integrated internal business process will improve SCM performance through reducing costs, shortening delivery time, providing appropriate feedback, maintaining low inventory levels, and increasing reliability. Internal integration creates easy access to operational data from integrated databases that connect various departments within the company. Internal integration in products and processes related to knowledge flow positively impacts its operational performance [32]. 
Internal integration that connects different functions can provide information for the company to be shared with its partners in order to be able to improve the ability of the company's production process [59]. Information technology enables operational effectiveness through superior customer service, efficient operational systems, and more efficient human resource management by creating a competitive advantage. The company's top management in investing in technology projects that integrate internal functions must ensure that they align with its strategic objectives. Managers need to develop relevant performance measures to gain the added advantage of using technology. The supply chain relies on information systems to identify changes in the market, and actions can be determined to deal with market changes by moving facilities, replacing suppliers, and outsourcing. Technology plays a vital role throughout all the supply chain stages to create a competitive advantage and more effective customer service. Internally, by sharing information, the company can build cohesiveness among functions that can increase the logistics services supply chain's integration capability. Thus, it has an impact on supply chain performance [50].

Integrated information technology can create the highest potential in improving operational performance and overall company performance when aligned with its strategic objectives. The company's strategic goal is to provide different products/services for its customers. The use of information technology also allows companies to track buyers' buying habits, determine fluctuations in the sales of seasonal products, and track the impact of marketing by comparing changes in product demand with the marketing style the company has done. Information technology can improve customer service and save inventory costs through collaboration between parts in the supply chain. Supply chain performance is a subset of company performance. Decisions on adoption and use of information technology are based on the supply chain's operational efficiency to improve overall company performance.

\section{Hypotheses 7 (H7). Internal integration affects firm performance.}

\subsection{Relationship between Green Supply Chain Management and Firm Performance}

The use of GSCM in manufacturing companies will provide changes to the procurement system, its operational system, and its marketing system to increase its competitiveness. GSCM integrates companies to pay attention to the environment in supply chain flow activities related to product design, material procurement, supplier selection, company manufacturing processes, sending finished products to customers, and the end of products after use [12]. GSCM on green purchasing companies can positively impact operational performance associated with reducing production costs, operating flexibility, and improving quality [3]. GSCM has an impact on the financial performance of 500 top US green companies [61].

Practical green supply chain related to supplier selection and evaluation of material suppliers to the company, vendor managed inventory, investment recovery, eco-design, packaging environment, reverse logistics, and partnership with customers impact manufacturing companies' performance [1]. The company's supply chain collaboration builds with external parties, especially suppliers, impacts company performance [62]. The focus of GSCM is the procurement of environmentally friendly materials that impact the company's business performance related to the provision of products and services [27]. Green purchasing focuses on supplier selection and developing a stable production process. Research in the United States of America manufacturing industry has shown that green supply chain management positively impacts manufacturing companies' environmental and economic performance [16,63]. A similar study has also been performed in Thailand with the companies certified with ISO 14001, and the result indicated that green supply chain management implementation affects the environmental, economic, and intangible performance of the companies [4]. Research by [64] in the Romanian mining entities has shown that firm performance could be improved by optimizing the green business strategy 
and emission inventories. Based on the above arguments, the last hypothesis is determined as follow:

Hypotheses 8 (H8). Green supply chain management affects firm performance in the company.

Those relationships between every two constructs and the proposed hypothesis, as described previously, are demonstrated in Figure 1.

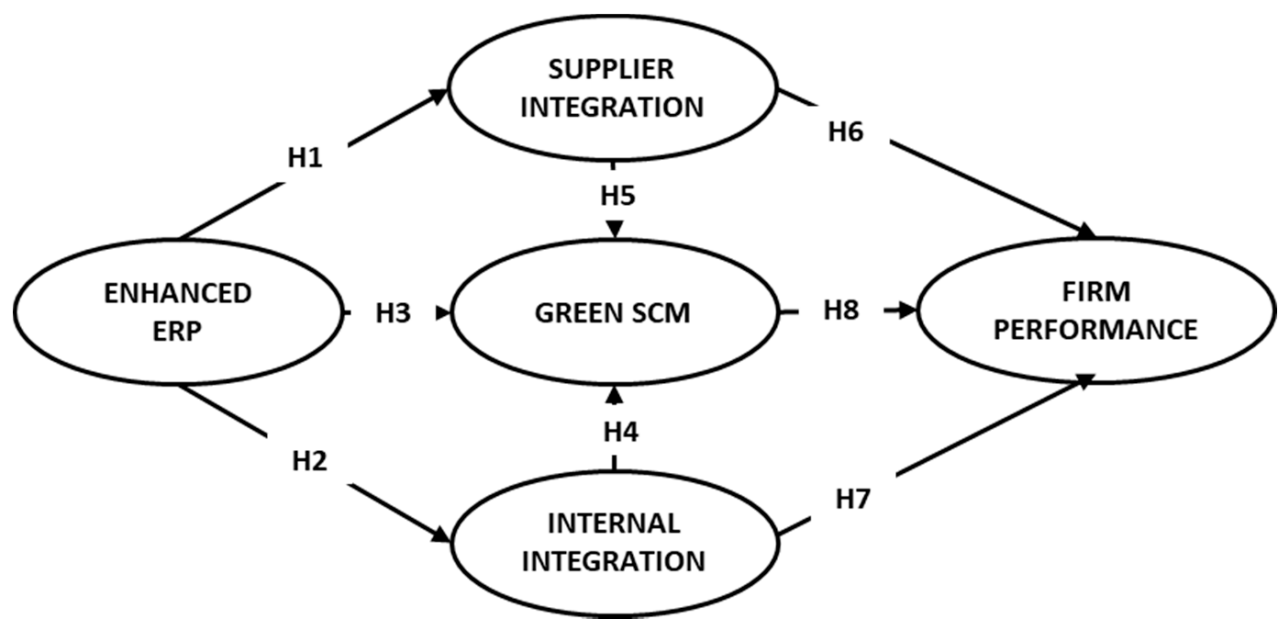

Figure 1. The Proposed Research Model and Related Hypothesis.

\section{Research Method}

This research concerns the companies that always upgrade their ERP to copy with the on-going business process development called enhanced ERP. The suitability of ERP on an on-going basis improves its internal and external integration, enabling companies to implement the GSCM strategy to improve their performance (Figure 1). This study has surveyed the population of 243 manufacturing companies domiciled in East Java, Indonesia, which have implemented ERP for more than four years. Besides, the selected companies also have been certified with ISO 14,000 in the environmental management system. Data collection used a questionnaire designed with a five-point Likert scale with $1=$ strongly disagree up to 5 = strongly agree. One hundred fifty (150) students of operation management assisted the questionnaire distribution, and each student was assigned responsibility for one company. It took three months to collect the questionnaires, and of the 150, 135 questionnaires were returned and considered valid for the analysis. The questionnaires distribution used the google form link and postal mail sent to the company public relation department and then forwarded to the appropriate respondent with the predetermined criteria. The respondent is a supervisor level or higher in charge of IT, production, purchasing, or logistic. The supervisor level or higher in these departments is considered knowledgeable concerning the company operation and policies and understands the study's context

Data analysis of this study used the Partial Least Square (PLS) technique using smartPLS software version 3.0. Data analysis examines two elements of the model, which are the outer and inner model. The outer model analysis assesses the validity (convergent and discriminant validity) and reliability of the indicators. The outer loading value represents convergent validity, and the cross-loading value represents discriminant validity. At the same time, the inner model analysis examines the predetermined hypotheses. The indicators are considered valid when the outer loading value is greater than 0.5 , and the outer loading is greater than the cross-loading value [65]. Table 1 demonstrated the analysis result of outer loading, cross-loading, and the indicator score means value. The score means of the indicator's value is in the range of 3.9030 and 4.3358 . This value represented the average score of all responses on each indicator. 
Table 1. Test Results of Outer Loading, Cross Loading, and Score Means.

\begin{tabular}{|c|c|c|c|c|c|c|}
\hline Indicator * & Enhanced ERP & $\begin{array}{c}\text { Firm } \\
\text { Performance }\end{array}$ & GSCM & $\begin{array}{c}\text { Internal } \\
\text { Integration }\end{array}$ & $\begin{array}{c}\text { Supplier } \\
\text { Integration }\end{array}$ & Score Means \\
\hline EERP1 & 0.815 & 0.506 & 0.535 & 0.432 & 0.582 & 4.0448 \\
\hline EERP2 & 0.703 & 0.437 & 0.446 & 0.468 & 0.522 & 4.1418 \\
\hline EERP3 & 0.775 & 0.505 & 0.455 & 0.443 & 0.579 & 4.2612 \\
\hline EERP4 & 0.773 & 0.517 & 0.586 & 0.426 & 0.546 & 4.0447 \\
\hline EERP5 & 0.767 & 0.498 & 0.555 & 0.422 & 0.536 & 4.0224 \\
\hline FP1 & 0.568 & 0.816 & 0.524 & 0.442 & 0.510 & 4.0149 \\
\hline FP2 & 0.467 & 0.774 & 0.514 & 0.537 & 0.453 & 4.1567 \\
\hline FP3 & 0.473 & 0.759 & 0.483 & 0.435 & 0.500 & 4.2015 \\
\hline FP4 & 0.374 & 0.668 & 0.494 & 0.478 & 0.529 & 4.2388 \\
\hline FP5 & 0.569 & 0.700 & 0.544 & 0.556 & 0.578 & 4.0821 \\
\hline GSCM1 & 0.515 & 0.467 & 0.667 & 0.455 & 0.464 & 4.1343 \\
\hline GSCM2 & 0.417 & 0.406 & 0.701 & 0.407 & 0.506 & 4.1866 \\
\hline GSCM3 & 0.489 & 0.583 & 0.795 & 0.492 & 0.450 & 3.9925 \\
\hline GSCM4 & 0.441 & 0.502 & 0.769 & 0.460 & 0.454 & 4.0149 \\
\hline GSCM5 & 0.371 & 0.470 & 0.721 & 0.580 & 0.588 & 4.1716 \\
\hline In.I1 & 0.483 & 0.448 & 0.470 & 0.763 & 0.345 & 4.0821 \\
\hline In.I2 & 0.409 & 0.555 & 0.413 & 0.764 & 0.312 & 3.9030 \\
\hline In.I3 & 0.514 & 0.511 & 0.409 & 0.782 & 0.512 & 3.9254 \\
\hline In.I4 & 0.369 & 0.423 & 0.354 & 0.701 & 0.204 & 4.0149 \\
\hline In.I5 & 0.420 & 0.351 & 0.405 & 0.664 & 0.315 & 4.0598 \\
\hline S.In1 & 0.270 & 0.486 & 0.392 & 0.459 & 0.697 & 4.0597 \\
\hline S.In2 & 0.309 & 0.522 & 0.459 & 0.485 & 0.783 & 4.0820 \\
\hline S.In3 & 0.495 & 0.518 & 0.488 & 0.241 & 0.750 & 4.1417 \\
\hline S.In4 & 0.542 & 0.570 & 0.565 & 0.321 & 0.817 & 4.1717 \\
\hline S.In5 & 0.418 & 0.438 & 0.401 & 0.437 & 0.528 & 4.3358 \\
\hline
\end{tabular}

Note: * those indicators notation were defined in the literature review section.

The Enhanced ERP variable has the lowest outer loading value of 0.703 for the EERP2 indicator. Hence all indicators of Enhanced ERP are considered valid. The firm Performance indicators obtained the lowest value on FP4 with a value of 0.668 , which exceeds 0.5 , so that all indicators on Firm Performance are valid. GSCM has the lowest value for GSCM1 with a value of 0.667 ; hence, all the indicators are valid. Similarly, the internal integration has the lowest value for the In.I5 indicator at 0.664 and above 0.5. The Supplier Integration also indicated that all its indicators have outer loading values greater than 0.5. Besides the validity, the outer model also assesses the reliability of each variable's block of indicators. The reliability is assessed using the Cronbach's Alpha, rho_A, composite reliability with the minimum acceptable value of 0.70 , and AVE with the minimum acceptable value of 0.5 [65]. Table 2 demonstrated that all the values are greater than the minimum value; hence all indicators are considered valid and reliable. Since the outer model is considered valid and reliable, further analysis for the hypothesis testing is allowed. Table 2 also indicated the value of $R^{2}$. The value of $R^{2}$ is moderately between 0.325 and 0.675 . This result shows that each dependent variable's variance: firm performance, GSCM, internal integration, and supplier integration is moderately explained by its independent variable, respectively.

Table 2. Test Results of Reliability and $\mathrm{R}^{2}$

\begin{tabular}{lccccc}
\hline \multicolumn{1}{c}{ Variable's } & $\begin{array}{c}\text { Cronbach's } \\
\text { Alpha }\end{array}$ & rho_A & $\begin{array}{c}\text { Composite } \\
\text { Reliability }\end{array}$ & AVE & $\mathbf{R}^{\mathbf{2}}$ \\
\hline Enhanced ERP & 0.825 & 0.826 & 0.877 & 0.589 & - \\
Firm Performance & 0.798 & 0.800 & 0.861 & 0.555 & 0.675 \\
GSCM & 0.782 & 0.784 & 0.852 & 0.536 & 0.514 \\
Internal Integration & 0.788 & 0.794 & 0.855 & 0.542 & 0.325 \\
Supplier Integration & 0.761 & 0.769 & 0.842 & 0.521 & 0.520 \\
\hline
\end{tabular}




\section{Research Discussion and Analysis}

\subsection{Characteristics of Respondents}

Objects in this study are manufacturing companies in East Java, Indonesia. Research respondents work at the company with a minimum of four years of work experience to understand and experience the company where the employee works and the company's system. Distribution of questionnaires given to companies with the criteria of the total workforce found 43 companies had a workforce of fewer than 50 people, 16 companies had a workforce of more than 50 workers and less than 100 people, 13 companies had a workforce of more than 100 and less than 200 workers employment and companies that have a workforce of more than 200 totaling 63 companies. Based on the type of enhanced ERP system used, it was found that 35 companies used ERP SAP R/3, ten companies used Oracle, one company used BAAN, three companies used MFG Pro, one company used JD Edwards, eight companies used People Soft, and 77 The company develops its ERP system following the needs and capital of the company. Companies in East Java have implemented ERP, especially in developing ERP systems due to the company.

According to the company functions and integration, the ERP system self-development is designed according to key users and ERP end-users needs. The use of ERP for companies is essential and becomes a system that companies use together. The use of ERP in a company can be seen from the length of ERP implementation. Based on the ERP experience, 27 companies used it for four years, 24 companies for five years, 14 companies for six years, 12 companies for seven to eight years, 23 companies for nine to ten years. In general, all the samples have used the ERP for the long term and become a single system that needs to be adjusted according to the function, and ERP called enhanced ERP. This finding shows that the respondent's departmental companies already have information systems integration, and most of them are integrations that are developed by themselves to suit the systems in their respective companies.

Characteristics of respondents based on departments in companies that use ERP System shows that the highest number of ERP systems in a row is found in the Marketing and Production section. Based on Table 3, it is found that almost all departments have used ERP system as a function in their department and integration between functions. This result shows that the respondents in this study were respondents from key departments in supply chain management activities.

\subsection{Hypothesis Test Results}

The value of the path coefficient or inner model shows the level of significance in hypothesis testing. The coefficient score is the path indicated by T-statistics. Hypothesis testing is significant if the T-Statistic value is more than 1.96 with a significance level ( $p$-Value) of $5 \%$ or 0.05 . The iteration results obtained from the Smart PLS program also produce values original sample, the sample means, and standard deviation [65]. The original sample is a beta score unstandardized used to see the dependent variable's independent variable predictive nature. The sample mean is the average value of the sample generated from the iteration process. Standard deviation is a standard error.

The path coefficient analysis results in Table 4 and Figure 2 show the value of the path coefficient and the T-statistic value to verify and determine the hypotheses' significance. The result found that all hypotheses are empirically supported. Enhanced ERP affects firm performance, enhanced ERP influences GSCM, enhanced ERP impact internal integration, Enhanced ERP of supplier integration, GSCM against firm performance, internal integration of firm performance, internal integration of GSCM, supplier integration of firm performance, and supplier integration of GSCM. Table 4 shows the results of the calculations path coefficient using the Smart PLS program [66]. 
Table 3. Characteristics of Respondents by Department.

\begin{tabular}{clcc}
\hline No. & \multicolumn{1}{c}{ Department } & Number & Percentage \\
\hline 1 & Accounting & 11 & $8 \%$ \\
2 & Marketing & 28 & $21 \%$ \\
3 & PPIC & 4 & $3 \%$ \\
5 & Production & 22 & $16 \%$ \\
6 & Finance & 12 & $9 \%$ \\
7 & Sales & 7 & $5 \%$ \\
8 & General & 13 & $10 \%$ \\
9 & Purchasing & 9 & $7 \%$ \\
10 & SCM Department & 9 & $7 \%$ \\
11 & Human Resources Department & 6 & $4 \%$ \\
12 & Material Management & 6 & $4 \%$ \\
13 & Engineering & 5 & $4 \%$ \\
14 & IT Department & 3 & $2 \%$ \\
\hline \multicolumn{2}{r}{ Total } & 135 & $100 \%$ \\
\hline
\end{tabular}

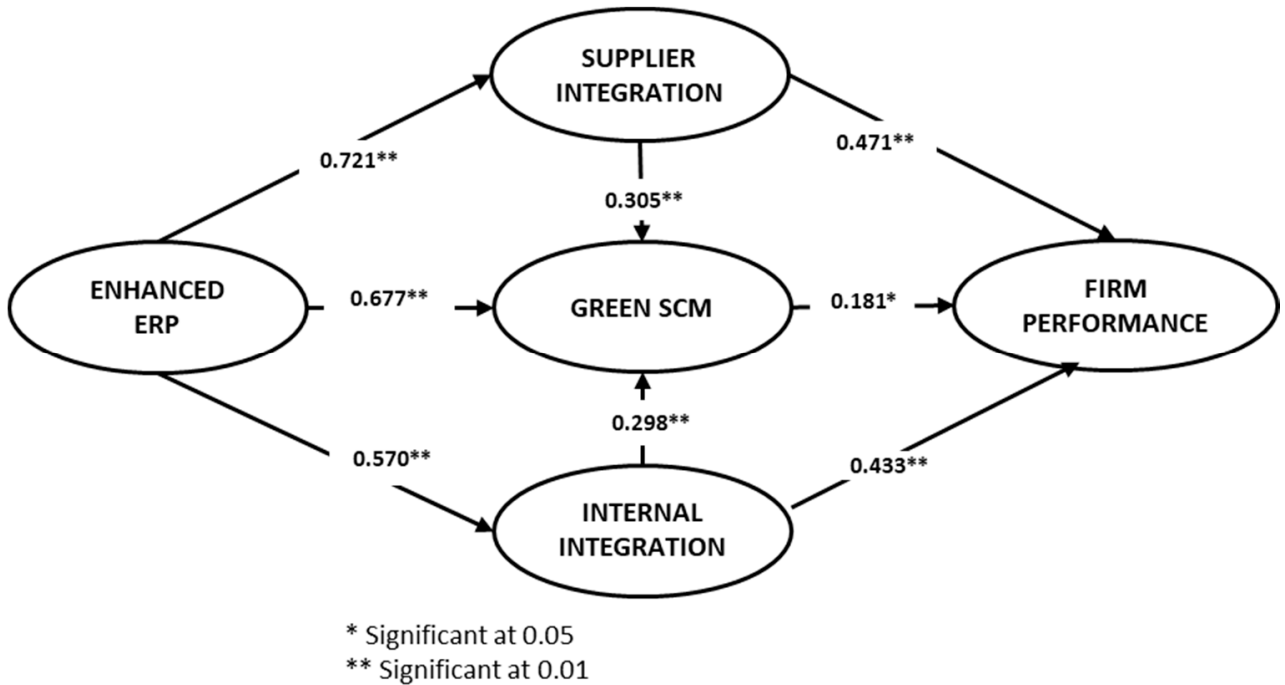

Figure 2. Research Model with the Path Coefficient.

Table 4. Test Results of Direct Effect Relationship.

\begin{tabular}{lcccc}
\hline \multicolumn{1}{c}{ Relationship } & Original Sample (O) & (ST.DEV) & T Statistics & $p$ Values \\
\hline Enhanced ERP $\rightarrow$ Supplier Integration (H1) & 0.721 & 0.046 & 15.556 & 0.000 \\
Enhanced ERP $\rightarrow$ Internal Integration (H2) & 0.570 & 0.053 & 10.798 & 0.000 \\
Enhanced ERP $\rightarrow$ GSCM (H3) & 0.677 & 0.045 & 5.128 & 0.000 \\
Internal Integration $\rightarrow$ GSCM (H4) & 0.298 & 0.081 & 3.687 & 0.000 \\
Supplier Integration $\rightarrow$ GSCM (H5) & 0.305 & 0.086 & 3.524 & 0.000 \\
Supplier Integration $\rightarrow$ Firm Performance (H6) & 0.471 & 0.058 & 8.154 & 0.000 \\
Internal Integration $\rightarrow$ Firm Performance (H7) & 0.443 & 0.060 & 7.373 & 0.000 \\
GSCM $\rightarrow$ Firm Performance (H8) & 0.181 & 0.076 & 2.476 & 0.013 \\
\hline
\end{tabular}

Based on Figure 2 and Table 4, the Enhanced ERP effect on GSCM obtained a path coefficient of 0.674 with $t$-statistics 15.128 and a $p$-value of 0.00 . This finding shows a significant positive effect between Enhanced ERP on GSCM in East Java manufacturing companies. The adjustment of Enhanced ERP will impact the implementation of GSCM in manufacturing companies. The study results indicated that manufacturing companies in East Java have maintained and developed the ERP system appropriate to the company's needs, end-user, and critical user and contributes to adopting green manufacturing practices. 
The companies have also developed the ERP system to comply with the environmentally friendly production system to pursue sustainable company's business. This study supports Al-Ghwayeen and Abdallah's results [12], which states that companies' integration with external parties can provide good eco-collaboration. This result supported the research results by [3] that internal integration in the company can support products' fulfillment in a natural environment [3].

The enhanced ERP hypothesis on internal integration obtained a path coefficient of 0.570 with a t-statistic of 10.798 and a $p$-value of 0.00 . This result indicates a significant positive effect between Enhanced ERP on internal integration in East Java manufacturing companies. That is, the adjustment of Enhanced ERP will have an impact on internal integration between functions in the department in manufacturing companies in East Java. ERP system integrates data between departments wholly and accurately and allows the departments to establish secure communication, coordination, and collaboration. The integration of related departments supports decision-making, such as the level of inventory. This study supports the research results by Demeter et al. [32], which stated that internal integration within the company enables all departments to access product availability and monitor operational processes.

The enhanced ERP hypothesis towards supplier integration obtained a path coefficient of 0.721 , a t-statistic of 15.566, and a $p$-Value of 0 . This result indicates a significant positive effect between Enhanced ERP on supplier integration in East Java manufacturing companies. This finding means that an enhanced ERP adjustment will impact sharing information between suppliers and manufacturing companies in East Java. The ERP system integrates the required data between suppliers and the company. When suppliers understand the company requirement, then coordination and collaboration can be settled based on the cooperation. This data integration enables information sharing and creates a mutual partnership between the two parties. This study supports the statement that its ERP system can impact collaboration with its suppliers [22]. Data integration within the company can integrate with the company's external partners [33]. This study also supports which states that ERP technology can establish integration with suppliers in coordinating planning and production processes [45].

GSCM affects the firm performance with a path coefficient of 0.188 , a t-statistic of 2.476 , and a $p$-Value of 0.013 . This result shows a significant favorable influence of GSCM on manufacturing companies' firm performance. The implementation of GSCM will have an impact on firm performance in manufacturing companies in East Java. The company conducted GSCM practices through the implementation of green purchasing and green manufacturing. The green supply chain management practices improved the company's performance by improving the quality and decreasing the production costs. This study confirmed that GSCM research provides quality products that fit customers' needs [12]. GSCM positively impacts operational performance due to reduced production costs and improved quality [3]. This study also supports Wang and Sarkis [61] and Appolloni et al. [16], which states that GSCM can increase company performance.

The hypothesis of internal integration on the firm performance obtained a path coefficient of 0.443 with a t-statistic of 7.373 and $p$-Value 0 . This result indicates a significant positive effect on the internal integration of firm performance in East Java's manufacturing companies. This finding implies that internal integration affects the company against firm performance of manufacturing companies in East Java. Internal integration in manufacturing companies enables all related departments to establish a joint decision supported by all departments. Joint decision-making is possible such as in reducing lead time and production costs. This study supports the states that internal integration impacts the company's operational performance [32].

The effect of internal integration on GSCM implementation has a path coefficient of 0.298 , a t-statistic of 3.687, and a $p$-value of 0.00 . This finding indicates a significant positive effect of the internal integration on GSCM. Internal integration between functions within the company provides an increase in GSCM implementation in manufacturing companies 
in East Java. Internal integration allows the management to make a joint decision involving all related departments in setting the company goals and policies to be achieved, including management decisions regarding using the green product. This research supports the results, stating that the internal integration between functions built by the company can increase its supply chain strategy [25].

The supplier integration influences the firm performance with a path coefficient of 0.469 , a t-statistic of 8.154, and a $p$-value of 0.00 . This finding indicates a significant positive effect between supplier integration on East Java's manufacturing companies' firm performance. The existence of supplier integration between suppliers and companies increases firm performance in manufacturing companies in East Java. The integration with the supplier requires communication, coordination, and collaboration that allows both parties to share innovative ideas. The innovation provides an improvement such as a reduced production cost, inventory cost, and firm performance. This research is in line with research that states that supplier integration by collaboration can reduce waste and efficiency as one of the company's goals [25]. State that the company's information sharing with partners in a timely, complete, reliable, and adequate manner can provide performance improvements for retail companies related to inventory costs, labor costs, transportation costs, operation costs, waste costs, and high profit [60].

The result indicated that supplier integration influences GSCM with a path coefficient of 0.305 , a t-statistic of 3.524, and a $p$-value of 0.00 . This result indicates a significant positive effect on supplier integration of GSCM in manufacturing companies in East Java. The existence of supplier integration between suppliers with the company increases GSCM implementation in East Java manufacturing companies. The company established an integration system for sharing ideas and information with suppliers and enhancing better collaboration to build a partnership with the suppliers, particularly in material procurement that complies with the environmentally friendly requirement. The partnerships that companies build with suppliers contribute to company sustainability in the future.

Table 5 indicated enhanced ERP indirect effect on firm performance with a path coefficient of 0.644 , a t-statistic of 17.059 , and a $p$-value of 0.00 . The enhanced ERP positively influences firm performance through the mediating role of supplier integration, internal integration, and GSCM adoption. Besides, the internal integration also indirectly affects the performance through the mediating role of GSCM as the t-value of $2.05>1.96$. Moreover, supplier integration indirectly affects firm performance through GSCM with a t value of 1.967. These results proved that ERP enhancement could improve the firm performance for the manufacturing companies. This study supports the previous study results stating that the enhanced ERP that suits the organization's needs can increase company performance and provide satisfaction for the users [34]. This study's central issue is green supply management (GSCM) adoption and firm performance. These findings demonstrated that the green supply chain management (GSCM) adoption improves firm performance with the requirement that the company also enhances its ERP, establishes an internal integration and supplier integration. The practice of the GSCM requires full support from the supplier and internal function to make sure the success of the GSCM.

Table 5. Test Results of Indirect Effect of Variables

\begin{tabular}{lcccc}
\hline \multicolumn{1}{c}{ Indirect Effect of Variable } & $\begin{array}{c}\text { Original } \\
\text { Sample }\end{array}$ & ST.DEV & T Statistics & $p$ Values \\
\hline Enhanced ERP $\rightarrow$ firm performance & 0.644 & 0.038 & 17.059 & 0.000 \\
Internal integration $\rightarrow$ firm performance & 0.056 & 0.027 & 2.067 & 0.039 \\
Supplier integration $\rightarrow$ firm performance & 0.057 & 0.029 & 1.967 & 0.049 \\
\hline
\end{tabular}

Data integration using ERP technology such as sales forecasting, production planning, production systems, human resources management, accounting management, finance, purchasing, and warehousing enables the organization to formulate better company strategies [8]. ERP is one of the most sophisticated systems that can integrate all departments in communication and information sharing [36]. 


\section{Conclusions}

The purpose of this study was to examine the impact of enhanced enterprise resource planning (ERP) on firm performance through supplier integration, internal integration, and green supply chain management. For this purpose, eight hypotheses have been proposed, and the result revealed that those hypotheses were empirically supported. Enhanced ERP systems affect supplier integration, internal integration, and GSCM. Internal integration and supplier integration influence green supply chain management and firm performance. Green supply chain management affects firm performance in the company. These findings supported the previous studies referred to in the formulation of the eight hypotheses. This study contributes to this important finding on the presence of the mediating role of the intervening variable. As shown on the indirect effect test result, the findings prove that enhanced ERP, supplier integration, and internal integration indirectly improve firm performance through the green supplier chain management's mediating role. This finding proved that green supply chain management, one of the recent trending issues resulting from the warming world due to the increasing level of pollution and forest damage, improves firm performance with the support from the supplier and internal function.

In line with the result and this research covers only the supplier and internal integration, this study has revealed the related issue to be a potential for new research by involving the customer demand change in the future. People are becoming more aware of the environmental issue as indicated by the mandatory requirement that the company trading in the global market should be certified with ISO standard in the environmental management system. This study provides a new insight for the manager that adopting green supply chain management contributes to the firm's performance with the support from the supplier and internal function and regular enhancement of the ERP following the business process development. This study also contributes to the on-going research in the field of supply chain management.

The limitation of this paper lies in the research population and the variables involved. The suggestion for further study might deal with variables most related to the pandemic, such as supply chain risk management and customer relationship management, to cover broader parties and functions involved in the supply chain network. Also, the next study might consider different industries such as the service industry instead of the manufacturing industry. Besides, this paper has a limited sample of manufacturing companies domiciled in East Java, Indonesia, which is not adequate to cover Indonesia.

This study might positively impact environmental sustainability since it has promoted the green environment approach. This approach may provide a positive impact on social life in the long term. Also, people would take care of this approach, making it one of the criteria when deciding to use the product.

Author Contributions: Z.J.H.T. prepare the original manuscript, background of research, literature review, conceptual model, methodology, and descriptive statistics; H.S. using software P.L.S., validation, reliability analysis, and hypothesis analysis; F.J., supervision, correcting writing errors, prepare discussion and conclusion, final article and final analysis. All authors have read and agreed to the published version of the manuscript.

Funding: This Research has been funded by Research and Community Outreach Petra Christian University for providing the postgraduate grant in funding this research [02/HBK-PENELITIAN/LPPM$\mathrm{UKP} / \mathrm{X} / 2020]$.

Data Availability Statement: The data presented in this study are available on request from the corresponding author. The data are not publicly available due to request from the respondents.

Acknowledgments: Authors would like to thank Research and Community Outreach Petra Christian University for providing the postgraduate grant in funding this research.

Conflicts of Interest: The authors declare no conflict of interest. 


\section{References}

1. Sundram, V.P.K.; Bahrin, A.S.; Munir, Z.B.A.; Zolait, A.H. The effect of supply chain information management and infrastructure information systems: The mediating role of supply chain integration towards manufacturing performance in Malaysia. J. Enterp. Inf. Manag. 2018, 31, 751-770. [CrossRef]

2. Al-Shboul, M.A.R.; Barber, K.D.; Garza-Reyes, J.A.; Kumar, V.; Abdi, M.R. The effect of supply chain management practices on supply chain and manufacturing firms' performance. J. Manuf. Technol. Manag. 2017, 28, 577-609. [CrossRef]

3. Famiyeh, S.; Kwarteng, A.; Asante-Darko, D.; Dadzie, S.A. Green supply chain management initiatives and competitive operational performance. Benchmarking Int. J. 2018, 25, 607-631. [CrossRef]

4. Laosirihongthong, T.; Adebanjo, D.; Tan, K.C. Green supply chain management practices and performance. Ind. Manag. Data Syst. 2013, 113, 1088-1109. [CrossRef]

5. Tarigan, Z.J.H.; Siagian, H.; Jie, F. The role of top management commitment to enhancing the competitive advantage through ERP integration and purchasing strategy. Int. J. Enterp. Inf. Syst. 2020, 16, 1-16. [CrossRef]

6. Zhao, L.; Huo, B.; Sun, L.; Zhao, X. The impact of supply chain risk on supply chain integration and company performance: A global investigation. Supply Chain Manag. Int. J. 2020, 18, 115-131. [CrossRef]

7. Wong, C.Y.; Boon-itt, S.; Wong, C.W.Y. The contingency effects of environmental uncertainty on the relationship between supply chain integration and operational performance. J. Oper. Manag. 2011, 29, 604-615. [CrossRef]

8. Jagoda, K.; Samaranayake, P. An integrated framework for ERP system implementation. Int. J. Acc. Inf. Manag. 2017, 25, 91-109. [CrossRef]

9. Ståhle, M.; Ahola, T.; Martinsuo, M. Cross-functional integration for managing customer information flows in project-based firms. Int. J. Proj. Manag. 2019, 37, 145-160. [CrossRef]

10. He, Y.; Lai, K.K.; Sun, H.; Chen, Y. The impact of supplier integration on customer integration and new product performance: The mediating role of manufacturing flexibility under trust theory. Int. J. Prod. Econ. 2014, 147, 260-270. [CrossRef]

11. Jajja, M.S.S.; Chatha, K.A.; Farooq, S. Impact of supply chain risk on agility performance: Mediating the role of supply chain integration. Int. J. Prod. Econ. 2018, 205, 118-138. [CrossRef]

12. Al-Ghwayeen, W.S.; Abdallah, A.B. Green supply chain management and export performance: The mediating role of environmental performance. J. Manuf. Technol. Manag. 2018, 29, 1233-1252. [CrossRef]

13. Sharma, S.; Gandhi, M.A. Exploring correlations in components of green supply chain practices and green supply chain performance. Compet. Rev. 2016, 26, 332-368. [CrossRef]

14. Wang, J.; Dai, J. Sustainable supply chain management practices and performance. Ind. Manag. Data Syst. 2018, 118, 2-21. [CrossRef]

15. Elcio, M.T.; Wong, C.Y. Towards a theory of multi-tier sustainable supply chains: A systematic literature review. Supply Chain Manag. Int. J. 2014, 19, 643-663. [CrossRef]

16. Appolloni, A.; Sun, H.; Jia, F.; Li, X. Green Procurement in the private sector: A state of the art review between 1996 and 2013. J. Clean. Prod. 2014, 85, 122-133. [CrossRef]

17. Susanty, A.; Hidayatika, S.; Jie, F. Using Green SCOR to measure performance of the supply chain of furniture industry Int. J. Agil. Syst. Manag. 2016, 9, 89-113. [CrossRef]

18. Luthra, S.; Garg, D.; Haleem, A. Critical success factors of green supply chain management for achieving sustainability in the Indian automobile industry. Prod. Plan. Control Manag. Oper. 2014, 1-24. [CrossRef]

19. Elvers, D.; Song, C.H. Conceptualizing a framework for customer integration during new product development of chemical companies. J. Bus. Ind. Mark. 2016, 31, 488-497. [CrossRef]

20. Danese, P.; Romano, P. The moderating role of supply network structure on the customer integration-efficiency relationship. Int. J. Oper. Prod. Manag. 2013, 33, 372-393. [CrossRef]

21. Ellstrőm, D. Supplier integration in the assortment management of builders' merchants. Int. J. Retail Distrib. Manag. 2015, 43, 634-651. [CrossRef]

22. Woo, C.; Kim, M.G.; Chung, Y.; Rho, J.J. Suppliers' communication capability and external green integration for green and financial performance in Korean construction industry. J. Clean. Prod. 2016, 112, 483-493. [CrossRef]

23. Lockström, M.; Lei, L. Antecedents to supplier integration in China: A partial least squares analysis. Int. J. Prod. Econ. 2013, 141, 295-306. [CrossRef]

24. Zsidisin, G.; Hartley, J.; Bernardes, E.; Saunders, L. Examining supply market scanning and internal communication climate as facilitators of supply chain integration. Supply Chain Manag. 2015, 20, 549-560. [CrossRef]

25. Graham, S. Antecedents to environmental supply chain strategies: The role of internal integration and environmental learning. Int. J. Prod. Econ. 2018, 197, 283-296. [CrossRef]

26. Khalaf, M.A.; Mokadem, M.Y.E. The relationship between internal integration and manufacturing flexibility in the Egyptian industry. Int. J. Qual. Serv. Sci. 2019, 11, 16-33. [CrossRef]

27. Lo, H.W.; Liou, J.J.H.; Wang, H.S.; Tsai, Y.S. An integrated model for solving problems in green supplier selection and order allocation. J. Clean. Prod. 2018, 190, 339-352. [CrossRef]

28. Riley, J.M.; Klein, R.; Miller, J.; Sridharan, V. How internal integration, information sharing, and training affect supply chain risk management capabilities. Int. J. Phys. Distrib. Logist. Manag. 2016, 46, 953-980. [CrossRef] 
29. Huo, B.; Qi, Y.; Wang, Z.; Zhao, X. The impact of supply chain integration on firm performance. Supply Chain Manag. 2014, 19, 369-384. [CrossRef]

30. Han, J.; Lu, H.; Trienekens, J.H.; Omta, S.W.F. The impact of supply chain integration on firm performance in the pork processing industry in China. Chin. Manag. Stud. 2013, 7, 230-252. [CrossRef]

31. Jayaram, J.; $\mathrm{Xu}, \mathrm{K}$. The relative influence of external versus internal integration on plant performance in China. Int. J. Prod. Econ. 2013, 146, 59-69. [CrossRef]

32. Demeter, K.; Szász, L.; Rácz, B.-G. The impact of subsidiaries' internal and external integration on operational performance. Int. J. Prod. Econ. 2016, 182, 73-85. [CrossRef]

33. Titah, R.; Shuraida, S.; Rekik, Y. Integration breach: Investigating the effect of internal and external information sharing and coordination on firm profit. Int. J. Prod. Econ. 2016, 181, 34-47. [CrossRef]

34. Panayiotou, N.A.; Gayialis, S.P.; Evangelopoulos, N.P.; Katimertzoglou, P.K. A business process modeling-enabled requirements engineering framework for ERP implementation. Bus. Process Manag. J. 2015, 21, 628-664. [CrossRef]

35. Iris, C.; Cebeci, U. Analyzing relationship between ERP utilization and lean manufacturing maturity of Turkish SMEs. J. Enterp. Inf. Manag. 2014, 27, 261-277. [CrossRef]

36. Almajali, D.A.; Masa'deh, R.; Tarhini, A. Antecedents of ERP systems implementation success: A study on Jordanian healthcare sector. J. Enterp. Inf. Manag. 2016, 29, 549-565. [CrossRef]

37. Alsulami, M.; Rahim, M.; Scheepers, H. Consolidating understanding of ERP conflicts: A dialectic perspective. In Proceedings of the Pacific Asia Conference on Information Systems (PACIS), Association for Information Systems (AIS), Chengdu, China, 24-28 June 2014.

38. Elkhani, N.; Soltani, S.; Ahmad, M.N. The effects of transformational leadership and ERP system self-efficacy on ERP system usage. J. Enterp. Inf. Manag. 2014, 27, 759-785. [CrossRef]

39. Tarigan, Z.J.H.; Lianto; Basana, S.R. The impact of organizational commitment on upgrading ERP for maintaining the quality of information and the ERP performance. IOP Conf. Ser. Mater. Sci. Eng. 2019, 473, 012051. [CrossRef]

40. Ince, H.; Imamoglu, S.Z.; Keskin, H.; Akgun, A.; Efe, M.N. The Impact of ERP Systems and Supply Chain Management Practices on Firm Performance: Case of Turkish Companies. Procedia Soc. Behav. Sci. 2013, 99, 1124-1133. [CrossRef]

41. Chong, A.Y.L.; Chan, F.T.S.; Ooi, K.B.; Sim, J.J. Can Malaysian firms improve organizational/innovation performance via SCM? Ind. Manag. Data Syst. 2011, 111, 410-431. [CrossRef]

42. Lee, C.W.; Kwon, W.G.; Severance, D. Relationship between supply chain performance and degree of linkage among suppliers, internal integration, and customers. Supply Chain Manag. Int. J. 2007, 12, 444-452. [CrossRef]

43. Truong, H.Q.; Sameiro, M.; Fernandes, A.C.; Sampaio, P.; Duong, B.A.T.; Duong, H.H.; Vilhenac, E. Supply chain management practices and firms' operational performance. Int. J. Qual. Reliab. Manag. 2017, 34, 176-193. [CrossRef]

44. Tarigan, Z.J.H.; Siagian, H.; Bua, R.R. The Impact of Information System Implementation to the Integrated System for Increasing the Supply Chain Performance of Manufacturing Companies. IOP Conf. Ser. Mater. Sci. Eng. 2018, 473, 012050. Available online: https:/ /iopscience.iop.org/article/10.1088/1757-899X/473/1/012050 (accessed on 7 April 2021).

45. Yang, Y.S.; Kull, T.J.; Nahm, A.Y.; Li, B. Attitudes toward supplier integration: The USA vs. China. Int. J. Oper. Prod. Manag. 2017, 37, 1094-1116. [CrossRef]

46. Bennett, D.; Klug, F. Logistics supplier integration in the automotive industry. Int. J. Oper. Prod. Manag. 2012, $32,1281-1305$. [CrossRef]

47. Mavengere, N.B. Information technology role in supply chain's strategic agility. Int. J. Agil. Syst. Manag. 2013, 6, 7-24. [CrossRef]

48. Flynn, B.B.; Huo, B.; Zhao, X. The impact of supply chain integration on performance: A contingency and configuration approach. J. Oper. Manag. 2010, 28, 58-71. [CrossRef]

49. Siagian, H.; Jade, K.; Tarigan, Z.J.H. The role of affective leadership in improving firm performance through the integrated internal system and external integration FMCG Industry. Int. J. Data Netw. Sci. 2020, 4, 365-372. [CrossRef]

50. Ju, Y.; Wang, Y.; Cheng, Y.; Jia, J. Investigating the impact factors of the logistics service supply chain for sustainable performance: Focused on integrators. Sustainability 2019, 11, 538. [CrossRef]

51. Tan, B.Q.; Wang, F.; Liu, J.; Kang, K.; Costa, F. A blockchain-based framework for green logistics in supply chains. Sustainability 2020, 12, 4656. [CrossRef]

52. Cai, S.; Jun, M.; Yang, Z. Implementing supply chain information integration in China: The role of institutional forces and trust. J. Oper. Manag. 2010, 28, 257-268. [CrossRef]

53. Yang, J.; Han, Q.; Zhou, J.; Yuan, C. The influence of environmental management practices and supply chain integration on technological innovation performance-evidence from China's manufacturing industry. Sustainability 2015, 7, 15342-15361. [CrossRef]

54. Paulraj, A. Understanding the relationships between internal resources and capabilities, sustainable supply management and organizational sustainability. J. Supply Chain Manag. 2011, 47, 19-37. [CrossRef]

55. Horn, P.; Scheffler, P.; Schiele, H. Internal integration as a pre-condition for external integration in global sourcing: A social capital perspective. Int. J. Prod. Econ. 2014, 153, 54-65. [CrossRef]

56. Mustafid; Karimariza, S.A.; Jie, F. Supply chain agility information systems with key factors for fashion industry competitiveness. Int. J. Agil. Syst. Manag. 2018, 11, 1-22. [CrossRef] 
57. Feng, T.; Li, T.; Sun, L.; Wang, D. External involvement and operational performance: The mediating role of internal integration. Chin. Manag. Stud. 2013, 7, 488-507. [CrossRef]

58. Blome, C.; Schoenherr, T.; Eckstein, D. The impact of knowledge transfer and complexity on supply chain flexibility: A knowledgebased view. Int. J. Prod. Econ. 2014, 147, 307-316. [CrossRef]

59. Prajogo, D.; Olhager, J. Supply chain integration and performance: The effects of long-term relationships, information technology and sharing, and logistic integration. Int. J. Prod. Econ. 2012, 135, 514-522. [CrossRef]

60. Jie, F.; Gengatharen, D. Australian food retail supply chain analysis. Bus. Process Manag. J. 2018, 25, 271-287. [CrossRef]

61. Wang, Z.; Sarkis, J. Investigating the relationship of sustainable supply chain management with corporate financial performance. Int. J. Prod. Perform. Manag. 2013, 62, 871-888. [CrossRef]

62. Cao, M.; Zhang, Q. Supply chain collaboration: Impact on collaborative advantage and firm performance. J. Oper. Manag. 2011, 29, 163-180. [CrossRef]

63. Green, K.W.; Zelbst, P.J.; Meacham, J.; Bhadauria, V.S. Green supply chain management practices: Impact on performance. Supply Chain Manag. Int. J. 2012, 13, 290-305. [CrossRef]

64. Oncioiu, I.; Căpuşneanu, S.; Oprea Constantin, D.-M.; Türkeș, M.; Topor, D.; Bîlcan, F.; Petrescu, A. Improving the Performance of Entities in the Mining Industry by Optimizing Green Business Processes and Emission Inventories. Processes 2019, 7, 543. [CrossRef]

65. Hair, J.F., Jr.; Sarstedt, M.; Hopkins, L.; Kuppelwieser, V.G. Partial least squares structural equation modeling (PLS-SEM): An emerging tool in business research. Eur. Bus. Rev. 2014, 26, 106-121. [CrossRef]

66. Hair, J.F.; Risher, J.J.; Sarstedt, M.; Ringle, C.M. When to use and how to report the results of PLS-SEM. Eur. Bus. Rev. 2019, 31, 2-24. [CrossRef] 